\title{
The Sealing Industry and the Architecture of the Tasman World
}

\section{Abstract}

This paper forms part of a collaborative project that aims to reframe the architectural histories of Australia and New Zealand by producing the first connected history of early colonial architecture in the Tasman world, a concept defined connectively as a working region of traffic across the Tasman Sea. In the early nineteenth century the Tasman world denoted a sub-set of imperial ventures between the south-eastern Australian colonies and pre(proto)-colonial New Zealand that were also linked commercially to British India and to imperial encroachments in China. Avoiding nationalist frameworks, the project expects to show how the earliest colonial architecture in 'our' region was an outcome of the industries that brought into being and shaped the colonial world. Seal hunting was foremost among these early European industries, providing the first export profits for the British colony of New South Wales. Yet the legacy of the sealing entrepreneurs based in New South Wales (here termed 'sealer dealers') and their frontier gangs of seal hunters remains unexamined in architectural history. Using historical methods, this paper argues that the sealing industry, while ephemeral in time, was foundational in place-making by establishing the Tasman world's earlycolonial built environment from the 1790s to about 1830 .

This study of the built infrastructure left by the sealing industry forms part of a research collaboration that aims to produce a new, critical account of early colonial architecture in south-eastern Australia and New Zealand. ${ }^{1}$ In the wake of Abel Tasman's partial charting of the outlines of lands he named New Holland and New Zealand in the 1640s, only since James Cook's voyages into the South Pacific did the Tasman Sea that separated them, which Cook named after his Dutch predecessor, hove into view on European maps from the late eighteenth century. This paper employs the concept of the "Tasman world" as a framework and context to revision and reconnect the early colonial architecture of New South Wales, the British empire's first claimed possession in Australia, and New Zealand. Coined by James Belich to incorporate Australia and New Zealand in a shared space that emerged with the expanding maritime frontiers of the British empire, the term reoriented an earlier Australian

\footnotetext{
${ }^{1}$ For the product of an early, scoping workshop see Globalisation, Entrepreneurship and the South Pacific: Reframing Australian Colonial Architecture 1800-1850, ed. Harriet Edquist and Stuart King (Melbourne \& Launceston: GESP Network, 2016).
} 
historiography that depicted New Zealand as part of New South Wales' "Pacific frontier", thanks to sealing among other trading and marauding activities. ${ }^{2}$ To provide clarification for intensive research into ties between Australia and New Zealand into the present, I duly defined the "Tasman world" in terms of movement, with an emphasis on the word traffic: that is, as a working region of traffic across the Tasman Sea between Australia and New Zealand: a region forever in flux. ${ }^{3}$ The Tasman world that exists today metamorphosed from the oceanic form of the 1770s to around 1830. In this era the Tasman world was linked strongly to British Asia and influenced by the activities of the East India Company, while its shape and extent was strongly influenced by seal hunting. The slaughter of fur seals was so prodigious that sealing voyages ceased in the South Pacific by the 1830s; an estimated 7 million southern seals were killed between 1780 and 1830, with thought only for plunder and profit. ${ }^{4}$

Commercial seal hunting is not typically associated with colonial architecture since it was an ephemeral enterprise. Yet, as we shall see, the sealing industry initiated trans-Tasman networks and built infrastructure that formed part of early colonial cities' fabric as well as that installed to pursue these sea mammals on the oceanic frontier. By adopting an oceanic perspective that views the early-colonial built environment in this region from the water, as

\footnotetext{
2 See, for example, D. R. Hainsworth, "Exploiting the Pacific Frontier: The New South Wales Sealing Industry, 1800-1921," Journal of Pacific History 2, no. 1 (1967): 59-75. As James Belich observed a generation later, sealing "was the first of a series of extractive industries ... in which the distinction between Australia and New Zealand was artificial." Belich, Making Peoples: A History of the New Zealanders from Polynesian Settlement to the End of the Nineteenth Century (Auckland: Allen Lane/Penguin Press, 1996), 131.

${ }^{3}$ Philippa Mein Smith, Peter Hempenstall and Shaun Goldfinch, Remaking the Tasman World (Christchurch: Canterbury University Press, 2008); Philippa Mein Smith, "The Tasman World," in The New Oxford History of New Zealand, ed. Giselle Byrnes (Melbourne: Oxford University Press, 2009), chap. 13. See also Philippa Mein Smith, "Tasman Connections," in Globalisation, Entrepreneurship and the South Pacific, ed. Edquist and King, 42 , among other additional publications on the history of multiple ties between Australia and New Zealand. ${ }^{44}$ Rhys Richards, Sealing in the Southern Oceans 1788-1833 (Paremata, Porirua: Paremata Press, 2010), 7, 14, 65.
} 
contemporaries did, this study relocates cultures and economies of colonial architecture; and identifies close relationships between houses and industrial structures in the first decades of British occupation. It explores ways in which architecture and building were elements in a global and imperial assemblage of corporate and private profit, speculation, and business ventures in this space in/between the southwest Pacific and Southern Oceans, and situates seal hunting as a key maritime industry within what historian Tony Ballantyne terms the "webs of empire" that encased the globe by the nineteenth century. ${ }^{5}$

Earlier than missionaries, sealers were "forerunners" of imperial encroachment into the southwest Pacific. ${ }^{6}$ In New Zealand, sealers and whalers were the British empire's "advance guard". ${ }^{7}$ In New South Wales, Australasia's "mother colony" where convictism was the foundational enterprise from 1788 , historians still debate why Britain established a penal outpost at Sydney. Writing in the 1960s, Tasmanian academic K. M. Dallas attributed the British colonisation of Australia to "commercial forces" rather than the dumping of convicts. ${ }^{8}$ Even if expelling convicts were a priority, convict port towns were located according to how strategic and useful these sites were for shipping. ${ }^{9} \mathrm{~A}$ product of raiding the oceans - sealskins - provided the first export staple for the British colony of New South Wales. Seal hunting marked the beginnings of Australian capitalism directed at external

\footnotetext{
${ }^{5}$ Tony Ballantyne, "Sealers, Whalers and the Entanglements of Empire," in Tony Ballantyne, Webs of Empire: Locating New Zealand's Colonial Past (Wellington: Bridget Williams Books, 2012), chap. 6. On ports, see Kenneth Morgan, "Building British Atlantic Port Cities: Bristol and Liverpool in the Eighteenth Century," in Building the British Atlantic World, ed. Daniel Maudlin and Bernard L. Herman (Chapel Hill: University of North Carolina Press, 2016), 212-28.

${ }^{6}$ James Belich, Making Peoples: A History of the New Zealanders From Polynesian Settlement to the End of the Nineteenth Century (Auckland: Allen Lane/The Penguin Press, 1996), 132.

${ }^{7}$ Ballantyne, Webs of Empire, 136.

${ }^{8}$ K. M. Dallas, Trading Posts or Penal Colonies: The Commercial Significance of Cook's New Holland Route to the Pacific (Hobart: Fullers Bookshop, 1969), 117.

${ }^{9}$ lbid., 88.
} 
markets. ${ }^{10}$ This paper's contribution lies in explaining how these beginnings were scripted by and in architecture.

One question not asked by architectural history until now is how sealing entrepreneurs, the capitalists who funded sealing ventures - whom I term "sealer dealers" - shaped the colonial built environment in the British settler colonies of New South Wales and its offshoots of Van Diemen's Land (Tasmania) and New Zealand (Aotearoa) before 1830. Another is how these capitalists in turn depended on the "grey architecture" of maritime industries, such as wharf facilities and warehouses, for their success. ${ }^{11}$ The method pursued is multi-historical in blending different approaches to history, including social history, traditional economic history as practised in the 1960s, and the latest trans-colonial and post-colonial perspectives. It also adapts the concept of staple theory to sealing as a maritime industry. ${ }^{12}$

As marine mammals, seals themselves demand an oceanic perspective since they resided on rocky islands and coasts from 40 degrees south of the Equator. So do their predators in the sealing industry who deployed their oceanic networks not only in the pursuit of seals in their

\footnotetext{
${ }^{10}$ Richard Pomfret, "The Staple Theory as an Approach to Canadian and Australian Economic Development," Australian Economic History Review 21, no. 2 (1981): 133-46. William J. Lines, Taming the Great South Land: A History of the Conquest of Nature in Australia (Sydney: Allen \& Unwin, 1991), 33, identifies the sealing industry with the beginnings of Australian capitalism but does not distinguish between domestic capitalism and enterprises in search of global markets.

${ }^{11}$ The term "grey architecture" is from G. A. Bremner, Johan Lagae and Mercedes Volait, "Intersecting Interests: Developments in Networks and Flows of Information and Expertise in Architectural History," Fabrications 26, no. 2 (2016): 235-6.

12 On staple theory, see Richard Pomfret, "The Staple Theory as an Approach to Canadian and Australian Economic Development," Australian Economic History Review 21, no. 2 (1981): 133-46. William J. Lines, Taming the Great South Land: A History of the Conquest of Nature in Australia (Sydney: Allen \& Unwin, 1991), 33 , identifies the sealing industry with the beginnings of Australian capitalism but does not distinguish between domestic capitalism and enterprises in search of global markets.
} 
coastal habitats but subsequently in the despatch of seal skins, used for clothing, and oil, used for lighting, across the Pacific Ocean to imperial markets in London and, preferably, China. Guided by Captain James Cook's charts and journals, the hunt for fur seals in this region commenced in Dusky Sound, Fiordland, New Zealand, in 1792. Military officers at Port Jackson chartered the Britannia, skippered by Captain William Raven, who deposited a gang of twelve men for 10 months in Dusky Sound before heading to the Cape of Good Hope to buy provisions for a starving Sydney. Raven had a three-year licence from the East India Company, and his gang collected a total of 4,500 skins for the China market. ${ }^{13}$

It is little recognised that these sealers from Sydney and a carpenter - an essential occupation in the colony - constructed the first European buildings in New Zealand at Luncheon Cove on Anchor Island in Dusky Sound (all named by Cook). (On the contrary, art historian Deidre Brown claims that the prefabricated house gifted by New South Wales governor Philip King to Te Pahi, paramount chief in the Bay of Islands, was the first “European house" built in New Zealand, in 1806.) ${ }^{14}$ In the South Island's remote Dusky Sound, the Sydney seamen built a series of wooden sealers' huts followed by a domestic dwelling house that Raven recorded was $40 \mathrm{ft}$ long $\times 18 \mathrm{ft}$ wide $\times 15 \mathrm{ft} \mathrm{high} .{ }^{15}$ This feat is less remembered than their building of a boat using local timber, which impressed Raven more

\footnotetext{
${ }^{13}$ A. Charles Begg and Neil C. Begg, The World of John Boultbee: Including an Account of Sealing in Australia and New Zealand (Christchurch: Whitcoulls, 1979), 125; D. R. Hainsworth, ed., Builders and Adventurers: The Traders and the Emergence of the Colony 1788-1821 (North Melbourne: Cassell Australia, 1968), 84; Robert McNab, Murihiku and the Southern Islands (Invercargill: William Smith, 1907), 39-40, 43, McNab, ed., Historical Records of New Zealand vol. 1 (Wellington: Government Printer, 1908), 177-8.

${ }^{14}$ Deidre Brown, "Te Pahi's Whare: The First European house in New Zealand," SAHANZ conference proceedings, University of Tasmania, 2012. Te Pahi was the first influential Maori leader to visit New South Wales, in 1805. Angela Ballara, "Te Pahi," Dictionary of New Zealand Biography, first published 1990, Te Ara the Encyclopedia of New Zealand, https://teara.govt.nz/en/biographies/1t53/te-pahi, accessed 27 March 2019.

${ }^{15}$ McNab, Murihiku, 40, McNab, ed., Historical Records, 177.
} 
because the boat provided a means of escape. Evidence of the dwelling house that the sealers built derives from the Britannia's ship's log, which New Zealand historian and politician Robert McNab found in Salem, Massachusetts during his searches for original documents relating to the colony's history that he collected a century after the Antipodean sealing rush. McNab published the "Log of the Britannia" as Appendix D in his history of southern New Zealand and the sub-antarctic islands in $1907 .{ }^{16}$ No sketches of the house have survived to indicate its actual form. Rather late in the twentieth century artist Gainor Jackson, whose usual subjects were harbours and shipping, reimagined the dwelling house as completed from indigenous materials and thatched with flax. ${ }^{17}$ Rendered indigenous by Jackson as 'made in New Zealand' after a fashion akin to a Maori whare, McNab's primary sources suggest this domestic house was in fact partially prefabricated from timber planks transported from New South Wales. ${ }^{18}$

[Figure 1 Dusky Sound about here: remnants of grey architecture: slipway and jetty, photograph by John Smith, 2017]

It is notable that there exists scant textual evidence for the construction of this building, let alone a picture drawn at the time. Nor has industrial archaeology yielded more than a few tantalising clues to its precise site, which would logically have been close to the source of fresh water at the head of Luncheon Cove. ${ }^{19}$ Partly this absence was the result of gendered

\footnotetext{
${ }^{16}$ See McNab, Murihiku, Appendix D, 322, for a brief reference to building the dwelling house and another house late in 1792.

17 Jackson's impression is reproduced in John Hall-Jones, The Fjords of Fiordland (Invercargill: Craig Printing Co., 2002), 28. A major problem with Hall-Jones' otherwise useful book is that it lacks footnote references. ${ }^{18}$ The most accessible and reliable source is McNab, ed., Historical Records, 177. I have yet to locate the journal of Robert Murry, an officer on the Britannia, which also refers to the building activities at Luncheon Cove.

${ }^{19}$ Ian Smith and Karl Gillies, archaeologists from the University of Otago, have studied this site.
} 
priorities in the maritime world. As already mentioned, richer testimony survives of boatbuilding in Luncheon Cove both on this initial sealing venture in 1792 and on subsequent voyages. McNab described Dusky Sound as a "sanatorium" for seamen and Luncheon Cove as a "shipbuilding yard". ${ }^{20}$ Shipbuilding was men's business whereas house building for shelter was a lower status and less glamorous activity associated with the domestic realm and women (if any were available) as opposed to adventure and moneymaking at sea. The longevity of these various structures is also significant. While sealing declined with the seals, the shipbuilding on which this industry depended continued, if spasmodically, in Dusky Sound to service subsequent ventures, such as whaling. Over time Luncheon Cove acquired a reputation among mariners as a site of shelter from storms and for shipping repairs and maintenance, extending the life of the "grey architecture" established in 1792 . Hence the remnants of a slipway and jetty - signs of shipbuilding survive today (see Figure 1) but not the dwelling house built to shelter the first sealers from Sydney.

In New Zealand, indigenous architecture reflected and informed early contact between newcomers and Maori. Sealers observed how the South Island's Ngai Tahu people lived in whare built of tree ferns with a sloping thatched roof supported by a central ridge pole. ${ }^{21}$ The sealer-adventurer John Boultbee described whare at the village of a prominent southern chief, also named Te Pahi, in the 1820s: some houses were $30 \mathrm{ft}$ long, of similar proportions to the first European buildings such as the one discussed above. Built of bark or reeds placed between horizontal rows of timber, the walls were low - about $2 \mathrm{ft}$ high - but

\footnotetext{
${ }^{20}$ McNab, Murihiku, 43, 44.

${ }^{21}$ Richards, 212-13. On whare, see Deidre Brown, Maori Architecture from fale to wharenui and beyond (Auckland: Raupo/Penguin, 2009).
} 
each structure had a high roof, and people slept on platforms about $3 \mathrm{ft}$ off the ground. ${ }^{22}$ Maori architecture was well documented because newcomers found it exotic, unlike their own maritime efforts.

Bass Strait to the southeast of the Australian continent - between Victoria and Tasmania rather than southern New Zealand was the site of the Tasman world's first sealing rush. Seal hunters rushed to gale-blasted Bass Strait from 1798 to 1803, amidst the wider imperial project to explore and map Australia's coastlines and harbours, an exercise in which the names of Matthew Flinders for England, and Nicolas Baudin for France, loom large as rival explorers and map makers. ${ }^{23}$ Having devastated the Bass Strait rookeries, sealers crossed the Tasman Sea to exploit the wild seas of Foveaux Strait. One problem for the historian rests in the secrecy that surrounded the extent of subsequent seal hunting in the Southern Ocean because the East India Company held a monopoly on trade in the south seas, which colonial entrepreneurs and ships' captains strove to subvert. As far as we know, the seal rush switched from Bass Strait to Foveaux Strait between 1803 and 1810; from there to the sub-Antarctic islands including the Antipodes Islands, Macquarie Island, and Campbell Island, and back to Foveaux Strait; and south to the Antarctic islands in the 1820 s. $^{24}$

The architecture of the Tasman world originated on this oceanic frontier, in camps near seal rookeries, as well as in early colonial port towns: first and foremost in Sydney. By crossing

\footnotetext{
${ }^{22}$ Boultbee's sketch is reproduced in Begg and Begg, 170, plate 111.

${ }^{23}$ Begg and Begg, 54-5; J. S. Cumpston, First Visitors to Bass Strait (Canberra: Roebuck Society, 1973), 7-8, 14; D. R. Hainsworth, The Sydney Traders: Simeon Lord and His Contemporaries 1788-1821, $2^{\text {nd }}$ ed. (Melbourne: Melbourne University Press, 1981 [1 $1^{\text {st }}$ pub. 1972]), 129; Richards, Sealing in the Southern Oceans. The stories of Flinders' and Baudin's competing imperial projects are told elsewhere, including in museum displays and biographies.

${ }^{24}$ Belich suggests sealing switched to Foveaux Strait about 1813; Richards suggests 1809.
} 
beaches, literally and metaphorically in both these spaces, sealers spawned early histories of cross-cultural engagement. ${ }^{25}$ Some stayed along the Tasman Sea's and Bass Strait's wild coasts and built homes for their mixed descent families. In Van Diemen's Land, a few independent straitsmen and their indigenous clan wives subsisted on the Bass Strait islands after the sealing rush and hunted seals on their own account. ${ }^{26}$ They erected houses and fenced gardens, protected by ti-trees from the prevailing westerly winds; in the Furneaux group, huts were built of split timber thatched with tussock grass. ${ }^{27}$ In Bass Strait communities Aboriginal women, who were the sea people in their culture, hunted the seals. So direct was the link between seals and homes that women placed seals' flippers in hollows beneath their huts. ${ }^{28}$

While the principal home base for sealer dealers was Port Jackson (Sydney and environs), shipbuilders and merchants also built wharves, slipways, and warehouses up rivers, at Hobart Town on the River Derwent and other satellite river towns. Two were Windsor on the Hawkesbury River north of Sydney and Port Dalrymple on the River Tamar in Van Diemen's Land, which became a supply depot for the industry in Bass Strait. Land grants to former convicts encouraged small fleets on the Hawkesbury River, which flowed out to the Tasman Sea.

Ex-convict opportunists featured prominently in the sealing industry. The biggest shipbuilder

\footnotetext{
25 The concept of beach crossing is adapted from Greg Dening, Islands and Beaches: Discourse on a Silent Land, Marquesas 1774-1880 (Honolulu: University of Hawaii Press, 1980).

${ }^{26}$ Patsy Cameron, Grease and Ochre: The Blending of Two Cultures at the Colonial Sea Frontier (Hobart: Fullers Bookshop/Riawunna Centre, University of Tasmania, 2011), 73, 90, 120.

27 Ibid., 104.

28 Information courtesy of Emma Lee, Oceanic Cultures and Connections workshop, IMAS, University of Tasmania, 5 September 2017.
} 
in New South Wales, James Underwood, who had a free passage on the First Fleet in 1788, accumulated his capital from sealing. His partner Henry Kable - another First Fleeter - was a ship's chandler and an emancipist trader. Together, Kable and Underwood despatched ships with sealing gangs to Bass Strait, signing up their first gang in $1800 .{ }^{29}$ Kable and Underwood were the first of the Sydney sealer dealers to send schooners to hunt for seals in New Zealand waters. ${ }^{30}$ In doing so they launched the trans-Tasman sealing industry proper. In 1805 they also entered into a partnership with Simeon Lord, another ex-convict. ${ }^{31}$ Transported to New South Wales for theft, Lord grew rich from retailing spirits and as an auctioneer, captain's agent, and sealing entrepreneur. Lord was the partner who marketed the skins. ${ }^{32}$ Together Lord, Underwood, and Kable built a shipyard on the Hawkesbury River. All three ex-convict business partners turned to domestic architecture to display their wealth and seek status and respectability by building "handsome houses" in Sydney. ${ }^{33}$

[Figure 2 about here - Simeon Lord's house]

Domestic building and functions were conjoined with business architecture and activity according to European practice. Lord built his house, of three storeys, and warehouses by the Tank Stream bridge in Sydney Cove (now Bridge St) to accommodate both his family and ships' officers and serve as a "rendezvous for captains and supercargoes". ${ }^{34}$ This site is still the epicentre of business in Sydney. Underwood also built a yard at the mouth of Sydney's

\footnotetext{
${ }^{29}$ Hainsworth, ed., Builders and Adventurers, 85; Cumpston, First Visitors to Bass Strait, 12-13.

${ }^{30}$ McNab, Murihiku, 80.

${ }^{31}$ Cumpston, 29; Hainsworth ed., Builders and Adventurers, 85.

32 D. R. Hainsworth, 'Kable, Henry (1763-1846)', Australian Dictionary of Biography [ADB].

${ }^{33}$ Hainsworth, ed., Builders and Adventurers, 18.

${ }^{34}$ D. R. Hainsworth, 'Lord, Simeon (1771-1840)', ADB; Old Sydney, illustrated by Sydney G. Smith, described by Charles H. Bertie (Sydney: Angus \& Robertson, 1911), 54-5.
} 
Tank Stream and a substantial, flat-roofed Georgian house behind it with a 'captain's walk' on the roof. ${ }^{35}$ These statement houses exceeded the governor's house in size and grandeur thanks to profits from the sealing industry.

[Figure 3 about here - Underwood's house and Lord's house and warehouses]

Similarly, the sealer, boatbuilder, and farmer John Grono operated his businesses from the Hawkesbury River, where he built a shipyard at Canning Reach. At that stage, the river was navigable for small ships as far as Windsor, further upstream. Grono, too, built a series of sealing ships and sailed them to Fiordland and Foveaux Strait where he obtained at least two hauls of 10,000 skins, and assembled shore bases and huts for sealing gangs. ${ }^{36}$ Back on the Hawkesbury, he built a home for his large family on high ground near Long Neck Swamp. ${ }^{37}$ Maps disclose relationships between sealer dealers; in this case, Grono's farm and shipping business was sited near a land grant to John Palmer, the colonial government's commissary-general, another sealer dealer who had connections to India. Unsurprisingly, frontier war broke out along the Hawkesbury in 1795 and again a decade later between land-grant holders and Aboriginal owners who lived, hunted and fished precisely where the white intruders built their "grey architecture". ${ }^{38}$

At Woolloomooloo, an Aboriginal meeting place by the harbour (now part of central

\footnotetext{
${ }^{35}$ Hainsworth, ed., Builders and Adventurers, 78.

${ }^{36}$ Begg and Begg, 124-5, 128.

37 Ibid., 129.

${ }^{38}$ Grace Karskens, The Colony: A History of Early Sydney (Crows Nest, NSW: Allen \& Unwin, 2009), 463, 466, 481, 490. On a 1795 massacre, see University of Newcastle, "Colonial Frontier Massacres in Eastern Australia," https://c21ch.newcastle.edu.au/colonialmassacres/map.php, accessed 31 October 2017.
} 
Sydney), Palmer built a "charming dwelling", one of the first permanent houses in the colony, developed a farm and erected a boatbuilding slip, where he constructed small vessels for the coastal trade and sealing in Bass Strait and in southern New Zealand. ${ }^{39}$ The image reproduced as Figure 4, painted by convict artist John Bolger in 1803, privileged the slipway and shipbuilding activities at Palmer's property over the substantial house, farm and farm buildings. Bolger's perspective was no doubt influenced by his second occupation as a ship's carpenter, but his painting conveys strongly that Palmer accumulated his wealth from shipping and the associated import and export of desirable products.

[Figure 4 about here - John Bolger, Walloomoolloo [Woolloomooloo: The Seat of Jn Palmer Esq Port Jackson, 1803, a928027h, Mitchell Library, Sydney]

From Woolloomooloo, John Palmer and his brother-in-law Robert Campbell, a merchant from Calcutta, engaged in sealing at the height of the sealing rush. A base in India gave Campbell's firm a global advantage, as Campbell's ships could transport seal skins to China and so navigate the East India Company's trade monopoly. To profit further from the sealing industry and the infant colony's thirst for liquor, Campbell - who was mainly a wine and spirit merchant in Calcutta - bought a house at The Rocks on the west side of Sydney Cove, where he built a substantial wharf and warehouses of sandstone that dominated the foreshore (see Figure 5). Campbell is now remembered as Sydney's first merchant. ${ }^{40}$ At The Rocks he continued to expand his home and business. Sealer dealers like Campbell

\footnotetext{
39 McNab, Murihiku, 79. The "charming" description is from Francois Peron, I, 373. See also Cumpston, 52. Peron was on the Baudin expedition.

${ }^{40}$ On Campbell, see Margaret Steven, Merchant Campbell 1769-1846: A Study of Colonial Trade (Melbourne: Oxford University Press, 1965) and Janette Holcomb, Early Merchant Families of Sydney: Speculation and Risk Management on the Fringes of Empire (North Melbourne: Australian Scholarly Publishing, 2013).
} 
developed intricate business networks, which were intertwined with their family networks. ${ }^{41}$ In 1803, Kable and Underwood arranged with Campbell to supply 300 tons of elephant seal oil to Campbell's wharf. ${ }^{42}$

[Figure 5 about here - Campbell's house, wharf, and warehouses, c. 1804 - nb links to India] Another merchant sealer, Thomas Reibey, also entered into a business agreement with Kable and Underwood. Thomas Reibey owned three boats by 1803 , including the sloop Raven that worked in Bass Strait, as did Kable and Underwood's gangs and Palmer's small vessels, and built up a substantial sealing enterprise. ${ }^{43} \mathrm{~A}$ former junior ship's officer with the East India Company, Reibey and his wife Mary Haydock - who was transported to New South Wales as a teenager for stealing a horse - first established themselves on land grants along the Hawkesbury River but later moved to Sydney, possibly to escape conflict. The Reibeys grew rich from sealing, among other ventures in grain and coal. After Thomas's death, Mary Reibey managed the family's shipping fleet, opened a warehouse in George Street in 1812, and became a property developer, erecting buildings in George Street, Macquarie Place, and by the King's Wharf in Sydney Cove. One of the richest entrepreneurs in the colony, Mary Reibey was a founder of the Bank of New South Wales, which opened in in Macquarie Place in 1817 in her house, which served as the bank's first business premises. From 1994 her portrait featured on the Australian $\$ 20$ note (an official gesture to mark the

\footnotetext{
${ }^{41}$ The intricate links between the Campbell and Palmer families, among others, are traced by Holcomb in Early Merchant Families of Sydney.

${ }^{42}$ Cumpston, 65.

${ }^{43}$ Cumpston, 31-2. See ADB entries.
} 
centennial of the passing of the vote for women in South Australia). ${ }^{44}$ Appropriately, Mary Reibey became visible to the Australian public as a businesswoman and historical figure through the circulation of money.

For the Reibey family, as for others, their accumulation of wealth from sealing benefited the next generation. Sons Thomas and James Reibey worked in partnership as shipping merchants and agents Thomas Reibey \& Co in Launceston, Van Diemen's Land from the 1820s, where they included sealing among their enterprises based at Launceston's Reibey's Wharf. This structure was sufficiently prominent in the life of the town, erected along alongside additional wharves beside the North Esk River parallel to the business district, that it featured in surveyors' maps of the settlement in following decades. ${ }^{45}$ The second generation of the Reibey family occupy a dominant place in the architectural history of Tasmania because Thomas Reibey Jnr built the historic Entally estate on a land grant near Launceston. Brother James, who lived next door, on the other hand, followed his mother into banking as one of the first directors of Van Diemen's Land's Derwent and Cornwall Banks. As might be expected, the close family connections between the sealing industry and the foundations of Australasian banking and commerce exemplified by the Reibey family in Sydney and Launceston are known to Australian economic historians. Yet the contribution of profits from the sealing industry to canonic buildings such as Entally House have escaped the jurisdiction of architectural history. Since the built environment is a constituent part of Australia's material culture, lacunae of this kind suggest that new frames of reference are

\footnotetext{
${ }^{44}$ G. P. Walsh, 'Reibey, Mary (1777-1855)', ADB; Karskens, 136; Old Sydney, 54; for Reibey on the \$20 note, see www.banknotes.rba.gov.au/australias-banknotes/banknotes-in-circulation/twenty-dollar, accessed 31 October 2017.

45 One example is: Plan of the town of Launceston VDL from actual survey by H. W. H. Smythe. Engd by J. Carmichael, Sydney, 1835, nla.obj-231435883, National Library of Australia, Canberra.
} 
necessary to understand, and re-plot, the cultural significance of early colonial sites and buildings.

To cite another Tasmanian example, Tasmanian identity Captain James Kelly began his career in sealing, whaling, and timber-getting as an apprentice to Kable and Underwood so that he could qualify as a master mariner. He built Rock House beside the Hobart Town Rivulet in 1817 as a family home, of which a drawing survives in local archives. In addition to his leading role in early colonial industries Kelly helped finance the building of Hobart's Theatre Royal and was a director of the Derwent and Tamar Fire, Marine and Life Assurance Co. ${ }^{46}$ In terms of "grey" architecture, however, Kelly is best remembered for building Hobart's Kelly Steps that allow walkers to negotiate the escarpment between Salamanca Place - home then and now to wharves and warehouses - and cottages in Kelly Street, Battery Point built for waterside and warehouse workers (see Figure 6).

[Figure 6 about here - Kelly Street January 1840 together with Kelly's initials etched into a column at the top of Kelly Steps, central Hobart, photograph by Richard Tremewan, 2017]

In conclusion, this case study of the sealing industry demonstrates that social and economic history approaches combined with the conceptual framework of the Tasman world, when defined as traffic, offer ways to rethink the early colonial building and architecture of Australia and New Zealand as examples of global and local, imperial and colonial enterprise. Relics of "grey architecture" such as the timber jetty posts and stone slipway in New

\footnotetext{
${ }^{46}$ E. R. Pretyman, 'Kelly, James (1791-1859)', ADB.
} 
Zealand's Dusky Sound in Figure 1 attest to the significance of the sealers who first built them and to the reach of their oceanic culture and connections. So do the grand mansions that the enterprising sealer dealers built in stone for home, business and display in colonial port towns, notably Sydney. At the shipyards in early New South Wales which these dealers built as bases for the sealing industry - principally in Sydney - their homes, offices, and warehouses, routinely housed together, embodied their relationships with the world, their trading networks with London, Calcutta and Canton, and the expressions of upward mobility that mattered so much to ex-convicts. We can only understand what and why these entrepreneurs built the structures they did by thinking in terms of how architecture scripts relationships and vice versa. This requires first locating forms of early colonial architecture within their global and colonial mercantile and cultural networks; and then interpreting those forms as the material embodiment of those networks, associated trade, business and cultural traffic.

Future research may show whether later industries in this region followed patterns established by sealing, and whether sealing reasserted in the Tasman world patterns already evident elsewhere. ${ }^{47}$ What this case study affirms is that the sealing industry gave a particular shape to the Tasman world from its inception post Cook's voyages to about 1830 when fur seals were so diminished in number that sealing as an industry ceased to be viable. That shape encompassed land and sea from New South Wales and the newly separated colony of Van Diemen's Land to the New Zealand archipelago and southern islands. This study demonstrates above all how the hunt for seals bestowed a foreshore architecture

\footnotetext{
${ }^{47}$ Whaling and the fur trade in the northern Pacific are obvious examples. Andrew Leach suggested these questions.
} 
across a new world: the Tasman world, our region (or one of them, depending on where the reader is situated), in ports open to the Tasman Sea, notably the principal beachhead of empire at Sydney, and in sealing grounds on the sea frontier. That foreshore architecture, grey and otherwise, invites further scrutiny through a bifocal lens of an architectural, oceanic history.

Philippa Mein Smith, University of Canterbury and University of Tasmania 